\section{STRUKTUR RUPA TOPENG BALI KLASIK}

\section{Wayan Suardana}

\section{FBS Universitas Negeri Yogyakarta}

\section{Abstract}

This study of classical Balinese masks aims at discovering and introducing the local and traditional Balinese values with a hope that the result might become input for mask development in Indonesia. The focus of the study is the mask forms, especially those related to symbols in religious belief.

The data were collected from references, informants chosen proportionally through purposive sampling and notes from historic sources as well as direct field notes.

The result shows that based on structure and form there is similarity between classical Balinese masks and puppets. The similarity can be seen from their dots, lines, shapes, colors, and textures. The form elements reached the peak since the fall of Majophit. The art traditions of East Java that had gone through che culture. The process enriched the existing arts, producing pajegan, panca, an bobondreasan masks. The masks are used as educational media applied in Hindu religious teachings and philosophy. The characters are taken from Mahabaratha and Ramayana epics.

Keywords: visual structure, classical Balinese masks

\section{A. Pendahuluan}

Indonesia memiliki beraneka seni budaya yang tersebar di seluruh daerah, masing-masing daerah memiliki peninggalan seni budaya tradisional yang kuat dan mempunyai ciri khas yang unik dan artistik sesuai dengan ciri daerahnya, peninggalan tersebut sebenarnya merupakan kekayaan bangsa Indonesia yang tiada taranya di dunia, dan bisa digunakan sebagai acuan untuk mengembangkan seni budaya masa kini berciri khas Indonesia.

Bali salah satu daerah di Indonesia yang memiliki seni budaya cukup beragam pula dan sampai saat ini masih tetap lestari,diantara seni budaya Bali tersebut diantaranya adalah seni Topeng, dalam aktivitas kesenian ia dapat digolongkan ke dalam seni pertunjukan, sedangkan sebagai hasil karya seni atau produk seni, topeng termasuk kedalam seni pahat karena memperlihatkan matra sebagai kajian bahasa rupa konvensional.

Karya seni topeng keberadaannya mungkin sama dengan perkembangan seni tari di Bali karena hal ini sangat berkaitan, dan sudah ada sejak jaman pra Hindhu (pra sejarah). Bentuk kesenian purba ini hampir sama dengan kesenian yang terdapat di daerah-daerah pedalaman Kalimantan, Sulawesi, Irian Jaya, dan

Imaji, Vol.4, No.1, Februari $2006: 74$ - 86 pulau-pulau lainnya di Nusantara dan dapat dijumpai pada masyarakat yang masih menganut kepercayaan animisme dan dinamisme. Kesenian ini berfungsi sebagai penolak bala, menyembuhkan penyakit, menurunkan hujan dan lain sebagainya. Sisa-sisa kebudayaan ini masih dapat kita jumpai di Bali pada tarian sakral seperti : Tari Sang Hyang Topeng Dedari, Barong Beruduk, tari Baris Cina, tari Perang Duri dan lain-lainnya.

Di Bali bentuk kesenian asli yang menggunakan topeng dan umumnya sangat tua di kenal Sang Hyang Topeng Dedari yang masih dapat kita jumpai saat ini. Jenis tarian ini dapat kita temuai di daerah-daerah pegunungan dan di pertunjukan dalam upacara-upacara keagamaan. Bagi masyarakat Bali, kalau ditinjau dari demensi vertikal kesenian tersebut merupakan media yang sangat penting dalam ritus keagamaan, kalau dilihat dari dimensi horisontal ia mempunyai fungsi komunal dalam kehidupan masyarakat.

Kebudayaan Bali mempunyai hubungan erat dengan kebudayaan Jawa yang dimulai sekitar abad-8 yang menyebabkan kesenian Bali berkembang karena masuknya pengaruh Hindu Jawa dan mencapai puncak keemasan abad ke-16 saat runtuhnya Majapahit, terjadinya migrasi besar-besaran ke Bali, kemudian menurunkan keseniannya pada masyarakat Bali dari generasi-ke generasi yang menciptakan berbagai bentuk kesenian seperti : tari Gambuh, Wayang Wong (orang) Wayang Kulit, tari topeng, Arja dan lain sebagainya.

Bentuk kesenian pertunjukan seperti tari topeng mulai berkembang di Bali pada saat ditaklukannya Bali oleh Maha Patih Gajah Mada, waktu itu Bali dalam pemerintahan raja Dalem Watu Renggong. Sisa peninggalan benda bersejarah berupa topeng yang berasal dari Jawa dan Bali pada masa itu dapat kita jumpai sekarang di Pura Penataran Tupeng, Blahbatuh.

\section{B. Sejarah Perkembangan Topeng Bali Klasik}

\section{Hakikat Topeng}

Topeng diartikan sebagai penutup muka yang dibuat dari kayu (kertas dan sebagainya) yang berupa muka orang (binatang dan sebagainya) Istilah topeng dapat mempunyai banyak pengertian : Oleh Karena itu perlu diberi penjelasan untuk memperoleh kesatuan pendapat dan seragam pemikiran sesuai dengan tujuan dari penulisan ini

Istilah topeng dalam percakapan sehari-hari sering kita dengar seperti, manusia bertopeng. Dalam artian ini kata topeng semata-mata berarti benda penutup "muka" agar identitas individu itu tidak dikenal, atau agar terjadi suatu perubahan dalam bentuk muka orang dari wujudnya semula.

Pengertian topeng sebagai penutup muka dengan mudah dapat kita perhatiakna dari gejala bahasa"formatif" (pembentukan kata), kata topeng berasal dari "tup" yang berarti tutup, kata tup ditambah saja dengan "eng" yang kemudian mengalami beberapa perubahan sehingga menjadi topeng> Arti lain dari topeng

Struktur Rupa Topeng Bali Klasik (I Wayan Suardana) 
adalah "tapel":"... for topeng simply means something presed against the face,I, e, a mask")

Topeng secara mudah adalah benda yang ditekankan pada muka yaitu tapel. Tapel atau topeng dapat dapat dibuat dari kayu, kertas tebal papier mache, dari kulit, kain dan bahan-bahan lainnya serta dapat digunakan untuk menutup muka atau sebagian dari muka.

Di Bali kata topeng memang dapat berarti tapel, akan tetapi kata topeng tidak selalu dapat diterjemahkan dengan tapel. Misalnya dalam kalimat "menonton" tari topeng" orang tidak akan mengatakan "mononton tari tapel" "manusia bertopeng" itu belum tentu berarti manusia itu memakai tapel. Tape atau topeng adalah hasil karya seni manusia sebagai perwujudan atau ekspresi tentang konsep bathinnya mengenai "face" atau binatang. Karya seni semacam in biasanya dibentuk sedemikian rupa sehingga dapat dipergunakan untuk menutup muka manusia, dengan demikian selanjutnya dapat diperkirakan bahwa timbulnya tari toeng yang di Bali biasanya disebut saja topeng dan dalam perkembangannya kita kenal dengan drama tari toeng. Unsur khas dari Drama Tari topeng adalah bahwa atau sebagian penarinya menggunakan tapel.

Dari uraian diatas dapat diambil suatu kesimpulan bahwa topeng sebagai karya seni yang berwujud " muka"(face) manusia atau binatang sebagai penutup muka, dan merupakan unsur penting dalam tari atau drama tari topeng.

\section{Sejarah Perkembangan Keseniaan}

Kehidupan seni budaya Bali mencapai puncaknya pada jaman Bali Klasik, pada pemerintah Dalem Watu Renggong di Gelgel pada tahun 14601550. Demikian pula dapat diperkiraan bahwa kesenian topeng merupakan proses kelanjutan dari pertunjukan tari topeng primitif yang sudah ada sejak jaman pra Hindu.

Kapan mulai orang membuat topeng atau pertunjukan tari topeng di Bali belum dapat dipastikan tapi diperkirakan sudah dikenal sejak jaman prasejarah. Bukti-bukti yang tertua yaitu adanya arca Bhairawa yang sedang menari di simpan di pura Kebo Edan dan Catur kaya dari Pejeng juga dalam sikap menari, dan keduanya mengenakan topeng. Bukti tertulis yang menunjuk perkembangan tari topeng di Bali seperti : prasasti Bebetin yang berangka tahun 818 saka atau 896 masehi yang isinya, menyebut kata " pertapukan " yang berarti penari topeng Demikian pula prasasti Blantik yang berangka tahun 980 Caka atau 1058 masehi serta prasasti Gurunpai yang bertulisan " atapukan " yang artinya topeng.

Perkembangan kesenian topeng di Bali juga mendapat pengaruh dari luar yaitu Hindu-Budha dari India lewat Jawa Timur pada Jaman Majapahit, disebutkan tari topeng sangat subur dikerajaan itu, hal tersebut dapat ditemukan pada relief candi dan dalam kitab Negara Kertagama, Dimana raja Hayam Wuruk digambarkan mahir menarikan topeng atau karaket. Hingga sekarang dalam tari atau drama tari sering membawakan tokoh-tokoh Majapahit. Selain itu cerita panji juga menggunakan topeng.

Pengaruh kesenian topeng dari kerajaan Majapait ke Bali dapat dijumpai dengan adanya peninggalan 22 buah topeng yang masih tersimpan di Pura Dalem Penataran Topeng. Delapan buah topeng yang berasal dari Jawa sedangkan sisanyaTopeng dari Bali yang diberi nama masing-masing seperti : Hayam Wuruk, Gajah Mada, dan Papak Mada, I Gusti Penatih, Sri Aji Wengker, Dalaem Juru, Sri Bima Cili, Danghyang Kepakisan dan Arya Semaranata. Jenis topeng ini memakai pemegang yang berupa kayu yang menonjol pada bagian dalam topeng, cara memakainya dengan jalan menggigit kayu tersebut. Jenis topeng dari Bali umumnya memakai tali atau karet seperti yang kita kenal sekarang. Topeng-topeng tersebutsekarang dikeramatkan dan dikeluarkan pada upacara tertentu.

Bagaimana topeng-topeng tersebut sampai ada di Pura tersebut dan disimpan sebagai benda sakral. Menurut Babad Dalem, masa pemerintahan Dalem Watu Renggong pernah melamar putri Dalem Juru ( raja Blambangan ) yang bernama I Dewa Ayu Nibas. Sebelum Dalem Juru memutuskan untuk menolak atau menerima lamaran tersebut, secara diam-diam ia mengirim "Tukang gambarnya" ke Klungkung dengan maksud untuk mengambil gambar Dalem Watu Renggong sendiri. Gambar yang dibuatnya berwujud topeng, akan tetapi oleh si tukang gambar sengaja dibuatnya jelek.

Melihat gambar itu lalu Dalem Juru memutuskan untuk menolak lamaran Dalem watu Renggong. Dengan demikian maka Dalem watu Renggong sangat murka karena merasa dihina oleh Dalem Juru. Blambangan akhirnya diserang, dalam serangan pertamanya pimpinan prajurit Bali diserahkan kepada I Gusti Jelantik Made Tenganhan. Pimpinan ini mengalami kegagalan dan meninggal dalam peperangan itu.

Kemudian Dalem Bali mengutus panglima perangnya yang lain untuk memimpin pengempur Blambangan, yaitu Ngurah Djelantik Wajahan untuk "Menjarah" (perampasan). Barang-barang rampasan ini digunakan sebagai bukti bahwa ia telah berhasil menaklukan Blambangan. Diantara barang-barang yang dirampasnya itu adalah berupa dua buah gong, satu Kropak wayang gambuh dan satu dan satu buah peti yang berisi topeng yang kemudian diserahkan kepada raja Klungkung Dalem Watu Renggong, beliau memegang tapuk pemerintahan sekitar tahun 1460-1550.

Setelah Dalem Watu Renggong wafat beliau digantikan oleh putra mahkotanya yang bernama Dalem Bekung yang memegang pemerintahan dari tahun 1550-1580. Kemudian setelah meninggal, Dalem Bekung diganti oleh Dalem Sagening yang memerintah pada tahun 1580-1665. Kemudian Dalem 
Sagening oleh putranya yang bernama Dalem Dimade dan memegang pemerintahan dari tahun 1665-1688.

Pada waktu pemerintahan Dalem Sagening ada tiga orang keturunan dari I Gusti Jelantik Pesimpangan yang bernama : I Gusti Ngurah Jelantik, I Gusti Gede Tusan dan I Gusti Gede Lebah. Ketiga putranya itu mengikuti jejak ayahnya yaitu menghamba di Puri Gelgel. Pada saat itu pula untuk pertama kalinya I Gusti Pering Jelantik menari Topeng Pajegan dengan memakai topeng-topeng yang diperoleh di Blambangan.

Dalem Dimade diganti oleh I Gusti Agung Maruti dan setelah beliau kalah, beliau diganti oleh Dalem Jambe dan Kerajaan Gelgel dipindahkan ke Klungkung dan disebut Semara Pura. Dalem Jambe diganti oleh Wirya Sirikan. Pada saat ini pula topeng hasil rampasan itu dipindahkan ke Blahbatuh, tepatnya sekarang berada di pura Penataran Tupeng.

\section{Jenis-Jenis Topeng}

Penggolongan ini didasarkan atas cara pemakaian atau menarikan topeng dalam suatu pertunjukan baik yang bersifat ritual maupun yang merupakan sajian artistik semata adalah sebagai berikut ; Pertama penari yang mengenakan topeng tanpa menghidupkan atau mengekspresikannya. Karena penari cenderung untuk tidak memasukkan dirinya kedalam alam atau dunia topeng yang ditarikan, topeng sering kali menjadi beku atau kaku dan tidak bernyawa. Kedua adalah penar mengenakan topeng untuk ditarikan, diekspresikan dan dihidupkan. Di sini penari senantiasa mengupayakan untuk "masuk" ke dalam topeng yang dipakainya. Oleh karena itu topeng-topeng menjadi bernafas, berjiwa dan hidup.

Cara yang pertama sering terdapat dalam pertunjukan topeng ritual untuk upacara keagamaan. Seperti topeng Sang Hyang Dedari terdapat di pura Jagon Agung ketewel Gianyar. Topeng Gajah Mada yang terdapat pura penataran tupeng Blahbatuh dan Barong Brutuk. Dalam pementasan ketiga kesenian ini kadang menimbulkan kerawuhan (mengalami trance ). Penari topeng ini biasanya disebut juru pundut.

Cara yang kedua, menari untuk menghidupkan dan mengekpresikan topeng terjadi pada pertunjukan yang merupakan sajian artistik atau hiburan, walaupun mempergunakan benda-benda sakral seperti Barong dan Rangda yang termasuk dalam jenis ini ;

a. Topeng Pajegan adalah dalam bahasa Bali yang berasal dari kata "pajeg" dan ditambah dengan sufik "an" menjadi pajegan yang berarti borongan, maksudnya seorang penari topeng memborong tapel dalam jumlah banyak untuk dipentaskan sendiri. Ia adalah one man actor, memborong semua tugas dan peranan di dalam pertunjukan topeng itu. Topeng Pajegan ini merupakan perkembangan kesenian topeng pada kerajaan Gelgel. b. Topeng Panca, dinamakan demikian karena jumlah pemain atau penarinya sebanyak lima orang topeng panca merupakan perkembangan selanjutnya dari Topeng Pajegan yang muncul sekitar tahun 1924 di Blahbatuh.

c. Topeng Sidhakarya, adalah sejenis tari topeng yang berfungsi simbolis bila ditilik dari penamaan "Sidhakarya"; Sidhanya (selesainya) karya (yadnya) yang sedang diselenggarakannya itu. Yaitu sebagai penutup upacara keagamaan. Selain itu berfungsi juga sebagai pengusir atau penolak bala yang mengganggu jalanya upacara.

d. Topeng Bobondresan, perkembangan yang paling akhir dari kesenian topeng yang bukan menggambarkan tokoh sejarah seperti tiga jenis yang telah disebut diatas tapi lebih fungsinya sebagai "interprenter" sebagai hamba raja, seperti pelawak, dengan raut topeng yang dibuat lucu dan nakal. Wayang Wong, adalah sejenis topeng yang mengambil tokoh yang disesuaikan thema cerita seperti Ramayana Tapel Wayang Wong juga disebut Barong Blasblasan, di mana hari-hari tertentu tapel-tapel itu dibawa berkeliling kedesa-desa yang disebut "ngelawang" berfungsi untuk menghilangkan penyakit di suatu desa dan mengusir roh-roh jahat. Barong dan Rangda, adalah jenis topeng yang mengambil atau menyerupai binatang dan denawa ( raksasa )

4. Topeng Sebagai Unsur Rupa

Perkembangan seni topeng seiring dengan perkembangan wayang kulit,terutama dalam penggarapan ekspresi wajah manusia dimana stilasi bentuk bagian-bagian wajah dan dalam pewarnaan. Maka tercapailah rumusan perwujudan berbagai tipe perwajahan yang disebut wanda, seperti tipe kasar, tipe halus, tipe ksatria, tipe galak, tipe raksasa, tipe penakawan, tipe dewa dan sebagainya.

Berdasarkan uraian tersebut diatas antara topeng dan wayang terdapat persamaan perkembangan dalam pencitaan bentuk rupa. Unsur-unsur rupa yang dimaksud meliputi : titik garis, bidang, bentuk. Warna, tekstur dan sebagainya.

Dalam hal ini yang dikaji dalam ini unsur rupa dalam topeng.

a. Garis

Dengan garis dapat diciptakan berbagai wujud ( shape ). Wujud yang terbentuk oleh garis menimbulkan kesan gerak, arah, atau kekuatan seperti juga watak dari garis itu sendiri. Dalam topeng karakter perwatakan dibentuk oleh garis sebagai kontur. Garis hadir pada wujud seperti mata, rambut, bibir, gigi, serta guratan kening pada topeng tua dan lain sebagainya. Peranan garis sangat menentukan dalam keberhasilan pembuatan topeng khususnya karakter topeng itu sendiri.

b. Bentuk

Bentuk atau wujud dari sebuah benda menjadi nyata karena adanya kontur. 
Garis tepi inilah yang memberikan wujud dari suatu benda. Kapan kita memakai kata bentuk (form) dan kapan memakai kata wujud atau rupa (shape). Pada umumnya bentuk adalah manifestasi fisik dari benda hidup sedang wujud dari benda mati. Itulah sebabnya dalam seni rupa orang banyak menggunakan kata wujud daripada bentuk untuk memperjelas bahwa wujud adalah hasil ciptaan seniman atau manusia.

Wujud dalam topeng yang dibuat oleh sangging ( seniman ) berasal dari berbagai sumber. Ada wujud yang berasal dari manusia, binatang, dewadewi, serta raksasa atau denawa.

c. Warna

Warna dalam karya seni topeng mempunyai peranan yang sangat penting, yaitu sebagai simbol dan perlambangan disamping sebagai nilai estetik. Warna merah melambangkan sifat yang suka marah dan galak, warna putih melambangkan sifat seperti lembut, bangsawan, dan suci. Warna dalam sen topeng dapat menentukan atau menunjuk karakter atau perwatakan yang dipunyai topeng.

C. Klasifikasi Topeng

Klasifikasi topeng ditinjau dari segi perwatakannya biasanya dilakukan atas dasar ekspresi serta sifat-sifat pembawaan topeng. Berdasarkan hal tersebut topeng biasanya digolongkan menjadi 6 golongan yaitu :

1. Topeng Bagus

Topeng Bagus memiliki ciri-ciri sebagai berikut: mata sipit atau segi tiga tumpul memakai cunda manik atau urna didahi, sebagai simbol dar kebijaksanaan dan kewicaksanaan. Bibir senyum dengan gigi kelihatan. Warna putih atau kehijauan yang melambangkan kesucian, kesuburan, atau kesejukan. Topeng yang termasuk golongan ini seperti, topeng Arsa Wijaya atau topeng Dalem.

2. Topeng Manis

Topeng Manis dengan ciri-ciri sebagai berikut : mata sipit senyum tanpa atau gigi kelihatan alis kecil memakai semi atau subeng warna putih atau putih kekuning-kuningan simbol dari watak gembira, tenang, luhur simpatik, topeng yang termasuk golongan jenis ini adalah topeng Putri bangsawan atau topeng putri yang mempunyai sifat baik

3. Topeng Aeng (Seram)

Topeng Aeng ditandai dengan ciri-ciri : mata bulat atau dideling (mendelik) memakai alis dan kumis tebal gigi kelihatan. Warna coklat atau merah tua, simbol dari watak keras, berani ataupun angkuh. topeng yang termasuk golongan ini adalah topeng yang berfungsi patih.
4. Topeng Lucu,

Topeng Lucu dengan ciri-ciri sebagai berikut : mata bulat tetapi berlubang, topeng hanya berwujud sebagian atau topo, ekspresi lucu, seperti tuli, cungih (sumbing), pemabuk dan lain-lain. Warna coklat atau aneka sesuai dengan watak. Topeng yang termasuk jenis ini adalah penasar ( penakawan ) dan jenis-jenis bebondresan.

5. Topeng Bagus Eang

Topeng ini ditampilkan dengan ciri-ciri : kombinasi antara Topeng Bagus dan Aeng. Topeng yang termasuk dalam golongan ini adalah pengelembarpengelembar atau yang berfunsi sebagai Arya.

6. Topeng Galak Manis

Topeng Galak Manis, mempunyai ciri sebagai berikut : mata deling (mendelik), senyum tanpa gigi warna coklat alis mata dan kumis terbuat dari bok (rambut) centung, topeng yang termasuk dalam golongan ini seperti para Arya, dan Punggawa (pengawal) raja.

Seni topeng jika ditinjau dari segi motif, memiliki lebih sedikit motif daripada seni rupa seperti patung dan lukisan. Motif topeng terbatas hingga wajah atau muka manusia dan binatang saja, sedangkan patung dan lukisan dapat ditambah dengan dua motif lagi yaitu motif tumbuhan serta motif yang diciptakan manusia itu sendiri. Motif yang terdapat dalam topeng lebih sederhana, karena ekspresinya tidak mungkin mengandung gerak sebagaimana patung, dan tidak mungkin mengandung tema atau lakon sebagaimana halnya sebuah lukisan (dramatik painting).

Dengan demikian motif topeng yang berlaku secara tradisi dapat digolongkan sebagai berikut :

a) Motif manusia dan segala sesuatu yang dimanusiakan seperti : Dewa-Dewi, Betara-Betari, Raksasa-Raksasi, dan sebagainya.

b) Motif binatang dan segala sesuatu yang dibinatangkan seperti : Empas (kurakura raksasa), Naga, Paksi atau Garuda, Singaambara, dan lain-lainnya. Dalam beberapa literatur segala sesuatu yang dimanusiakan disebut makhluk langit, sedangkan segala sesuatu yang dibinatangkan disebut binatang khayal (takhyul). Bagaimana perwujudan topeng diperkirakan seperti halnya dalam penciptaan wayang merupakan perwujudan dari roh nenek moyang atau roh para leluhur mereka.

D. Topeng sebagai Benda Seni

1. Kesinambungan Tradisi Seni Topeng

Perkembangan kesenian khususnya seni topeng di Bali mengalami masa kejayaan pada masa Bali Hindu Klasik namun kesenian topeng sudah ada sejak jaman pra Hindu dan kesinambungan kesenian tersebut tetap masih berlangsung

Struktur Rupa Topeng Bali Klasik (I Wayan Suardana) 
hingga sekarang. Pertunjukan topeng ini masih dapat kita saksikan pada harihari tertentu seperti, Topeng SangHyang Dedari atau SangHyang Legong yang dipentaskan didesa Ketewel Gianyar pada hari raya Pagerwesi dan di Desa Trunyan Kintamani kita dapat jumpai topeng Brutuk atau Betara Brutuk. Wujud topeng Brutuk ini mempunyai persamaan dengan topeng-topeng di Kalimantan Timur yang disebut Hudog. Topeng-topeng tersebut merupakan salah satu warisan dari kebudayaan primitif dan dipertunjukan untuk penyembahan leluhur dan sepenuhnya dedikasi mereka terhadap leluhur.

Perwujudan Topeng Brutuk raut muka yang bulat, mata sipit, gigi kelihatan, kontur yang kasar dan kaku untuk lebih memperlihatkan daya magis yang memancar diharapkan dari topeng tersebut. Berbeda dengan topeng SangHyang Dedari yang merupakan perwujudan dari wanita atau bidadari yang menampakan kontur yang lebih halus, mata tipe manis, bibir tanpa senyum, secara keseluruhan menampakan ekspresi dingin dan kaku namun memperlihatkan unsur magisnya.

Seperti ditulis oleh C.A. van Peursen (Strategi Kebudayaan), pada kebudayaan mitis, manusia dikuasai oleh alam pikiran mitologis, terpesona oleh daya-daya gaib alam dan tunduk kepadanya. Masyarakat model ini menganggap mitos merupakan bakat manusiawi Mereka juga menganggap alam ini penuh daya-daya gaib, penuh rahasia dan meresponnya secara primitif.

\section{Kesinambungan Kesenian Topeng di Bali}

Selain merupakan jalinan tradisi prasejarah juga mendapat pengaruh dari luar seperti kebudayaan Hindu-Budha yang datang dari India melalui Jawa juga mendapat pengaruh dari Cina. Hubungan kesenian antara Bali dan Cina diduga sudah berlangsung lama, dan dapat dipastikan bahwa nenek moyang dari berjenis barong yang ada di Bali berasal dari Singa Barong Cina yang muncul pada dinasti Tang, sekitar abad ke-7 sampai abad ke-10. Saat itu singa barong merupakan pengganti pertunjukan singa sesungguhnya dari sirkus. Dipertunjukan oleh orangorang yang melakukan perjalanan dan mengikuti festifal untuk mencari dana. Lalu oleh masyarakat di Bali diasosiasikan dengan Budha, Singa-Barong ini dipaka untuk upacara keagamaan seperti dalam pertunjukan Barong ngelawang ( keliling ) di Bali, barong ini dikenal dengan nama Barong Kedingkling.

Seperti juga wayang, peranan topeng dalam kesenian adalag sebagai media komunikasi atau pendidikan sesuai dengan ajaran dan falsafah Hindu. Sebagai pertunjukan tari yang berfungsi agama dimana tokoh-tokoh cerita yang dimainkan adalah mengambil cerita-cerita Ramayana, Mahabrata dan panji disamping tema mitologi, legenda dan cerita sejarah.

Meskipun pembuatan topeng untuk tarian agama sudah ada sejak kebudayaan pra Hindu, tapi sukar memperoleh penjelasan bagaimana rupa topeng

Imaji, Vol.4, No.1, Februari $2006: 74$ - 86 dari jaman Hindu. Sumber pengenalan dari perkembangan awal dari topeng Indonesia Hindu ialah dari kitab-kitab sastra Hindu atau dari pahatan dinding candi. Dalam hal ini topeng Bali Klasik, seperti juga dalam lukisan dan wayang dapat dijadikan sebagai petunjuk untuk mengenal kembali topeng Indonesia Hindu sebagai sarana tarian Klasik.

Sebagai karya ukir atau pahat topeng dan wayang mempunyai persamaan dalam perkembangan dalam penciptaan bentuk rupa, kemungkinan berasal dari hiasan pahatan candi Jawa Timur kemudian diteruskan pada masa zaman Islam. Penciptaan wujud topeng yang diilhami dari relief candi nampak jelas terlihat dengan adanya pertunjukan topeng untuk wayang yang dikenal dengan sebutan Wayang Wong pada zaman kerajaan Mataram kuno di Jawa Tengah. Perwujudan suatu ekspresi topeng mengambil tokoh-tokoh dalam cerita Ramayana seperti : Sri Rama, Laksamana, Dewi Sinta, Hanuman, Rahwana dan lain sebagainya.

Perkembangan atau gejala-gejala perubahan tradisi seni rupa India untuk menyesuaikan dengan kondisi alam dan lingkungan budaya Indonesia lebih nampak pada perkembangan seni rupa di Jawa Timur. Kecenderungan gaya wayang dengan stilasi bentuk tokoh cerita pada hiasan candi Jawa Timur menunjukan tradisi baru dalam seni hias Indonesia. Tidak hanya pada stilasi bentuk tapi juga dalam pengisian bidang haiasan yang penuh dan padat. Kenyataan ini dapat disimak padateknik pahatan hiasan yang relatif lebih rendah jika dibandingkan dengan pahatan candi Jawa Tengah. Adegan cerita Ramayana yang dipahat pada Candi Penataran adalah contoh adanya perubahan tersebut. Kekayaan hiasan candi Jawa Timur selain adanya unsur lokal seperti motif meander, tumpal, dan motif gunungandiperkaya dengan unsur luar seperti dari Cina yaitu motif awan dan bukit karang.

Bagaimana proses pembetukan atau wujud topeng kemungkinan hampir sama dengan proses pembentukan wayang yang berasal dari relief atau hiasan candi. Hiasan candi tampil lebih mengarah pada gaya dekoratif, perwujudan stilasi manusia tidak kaku tetapi tampil dalam perwujudan yang penuh dengan dinamika, mengambil sumber wiracerita dari Hindu seperti Ramayana pada relief Candi Prambanan dan Candi Penataran, Mahabarata serta cerita Panji pada Candi Sakelir di Gunung Penaggungan, dan Candi Surawana dengan cerita Arjuna Wiwaha. Dari perwujudan tokoh-tokoh pada adegan cerita hiasan candi, kira-kira dapat dibayangkan bentuk dan rupa wayang dari zaman Hindu sebagai karya seni.

Seperti telah disebutkan diatas bahwa wayang dan topeng mempunyai persamaan terutama dalam penggarapan ekspresi wajah manusia yang disebut dengan wanda, seperti tipe kasar, tipe halus, tipe galak dan sebagainya. Dalam seni lukis wayang Bali Klasik kita mengenal wanda ini yaitu : muka kemanisan, kekerasan, raksasa, wanita, dan muka tua dan perwujudan binatang. Topeng dan

Struktur Rupa Topeng Bali Klasik (I Wayan Suardana) 
wayang dibuat diperkirakan merupakan lambang atau perwujudan dari arwah nenek moyang dan raja yang dianggap titisan dari Dewa dan Batara.

\section{Kesenian dalam Masyarakat Bal}

Dalam perkembangan serta dinamika masyarakat Bali dalam berkesenian seperti diltulis oleh ilmuan C.A. van Peursen ( Strategi Kebudayaan, 1993 ) membagi kebudayaan dalam tiga katagori yaitu : mitis, ontologis, dan fungsional. Di Bali sampai sekarang masih menampakkan masyarakat yang hidup dalam ketiga alam pikiran tersebut.

Istilah kesenian atau seni dalam masyarakat Bali hampir tidak pernah kita temui, kesenian lebih bersifat mencoba mengidentifikasikan diri dari luluhnya bidang-bidang kehidupan. Kegiatan kesenian tidak bisa lepas dari adat, mitologi, dan filsafat yang ada. Sulit untuk membedakan seni dan bukan seni. Sama luluh dalam kehidupan yang utuh, tidak bisa kita membedakan seni, ilmu dan teknologi.

Pada awalnya seni bersifat sakral, kemudian kita lihat juga seni yang bersifat frofan. Disini sakral dikatakan lebih dahulu karena kegiatan sen awalnya memang lebih banyak ditunjukan kepada hal yang bersifat spiritual, gaib atau angker. Dalam tarian topeng Brutuk dan Topeng SangHyang Dedar dalam kehidupan mistisitu dua lingkungan menurut van Peursen : Dalam lingkungan pertama tarian bersifat sakaral berfungsi untuk menangkis mara bahaya, penyakit dan lain sebagainya, sedangkan dalam lingkungan yang kedua bersifat profan terjadi pada perbuatan sehari-hari.

Masa era Bali Hindu Klasik alam pikiran mistis ini berbaur dengan agama Hindu yang datang dari Jawa, dalam cerita-cerita babad dilukiskan para raja berpedar wajahnya sebagai Dewa Wisnu dan Dewa Surya, sementara permaisuri diibaratkan sebagai Dewi Ratih. Topeng Gajah Mada yang berasal dari zaman Dalem Watu Renggong sekarang masih tersimpan di Pura Penataran di Blahbatuh diumpamakan juga pejelmaan Batara Wisnu. Dalam masa pemerintahan Dalem Watu Renggong ini kesenian yang mempunyai nilai mitologi ini berkembang seperti lukisan-lukisan wayang ( $p a r b a$ ) di langit-langit Kertha Gosa.

Sekalipun kita mengenal masyarakat Bali masih membaurkan subyek dan obyek akan tetapi kita tidak bisa memungkiri adanya keahlihan pada individu atau kelompok. Mereka belum sepenuhnya profesional dalam arti menggunakan keahlian itu semata-mata untuk mendapatkan uang.,( Koetjoriningrat, 1975 : 2021 ) Meskipun seseorang dianggap ahli dalam kesenian, bukan berarti ia tidak ahli dalam mengkaji fisafat atau agama.

Keahlian-keahlian dalam masyarakat Bali itu berupa :

a) Undagi : tidak bisa disamakan dengan seorang arsitek misalnya, kendatipun pekerjaannya sama-sama merancang bangunan. Seorang undagi harus tahu atau mengenal filsafat, mitologi, adat, lingkungan, daerahnya, sebelum merancang. Pekerjaan tidak saja merancang rumah akan tetapi juga merancang bade, wadah untuk ngaben, membuat planologi rumah, merencanakan bentuk serta lingkungan persembahyangan ( sanngah, pura ).

b) Sangging : Seperti Undagi, seorang sangging harus mengguasai pula segala yang bersifat spiritual. Keahliannya dalam bidang lukisan, patung, topeng, wayang dan lain sebagainya.

c) Pande : adalah ahli dalam membuat barang-barang dari logam. Selanjutnya kita mengenal pande emas. Pande besi, ahli barang-barang dari besi. Seperti telah diungkapkan diatas, ahli ini tidak saja melulu bekerja di bidang keahliannya. Pada waktu yang sama ia harus mampu bertani atau berkebun. Semua dikerjakan dengan kesungguhan yang tidak terlalu mementingkan imbalan uang dan ia tidak pernah menyatakan dirinya ahli atau seniman serta nama sejenisnya. Yang dipentingkan adalah pengabdian pada Tuhan, masyarakat dan lingkungan alamnya.

\section{E. Penutup}

Topeng senagai karya seni ukir tepatnya raut topeng, karena teknik pembuatan dengan pisau raut. Dalam perkembangannya seiring dengan perkembangan wayang kulit, terutama dalam penggarapan ekspresi wajah dan dalam pewarnaan. Sehingga melahirkan berbagai jenis karakter wajah yang disebut dengan wanda, karena antara topeng dan wayang memiliki persamaan dalam penciptaan bentuk.

Topeng dalam kesenian Bali Klasik mengalami perkembangan, dan mengalami puncaknya sejak jatuhnya Majapahit akibat datangnya Islam ke Indonesia. Tradisi kesenian Jawa Timur yang telah mengalami sintesa berlanjut di Bali dan beralkurasi dengan budaya setempat. Hal tersebut memperkaya bentukbentuk kesenian yang ada. Pada era ini, tepatnya zaman pemerintahan Dalam Watu Renggong banyak melahirkan topeng dalam bentuk drama tari seperti : topeng Pajegan, Topeng Panca, Wayang Wong sampai yang termuda Topeng Bebondresan dapat diperkirakan merupakan kesinambungan tradisi jaman tersebut.

Topeng begitu juga wayang sebagai drama tari yang dipertunjukan untuk gama juga merupakan media pendidikan sesuai dengan ajaran dan falsafah agama Hindu. Dimana tokoh-tokoh yang dimainkan biasanya mengambil cerita seperti Mahabrata dan Ramayana serta panji dan juga mengambil cerita mitologi, legenda dan sejarah. Walaupun topeng sebenarnya telah ada sejak zaman pra-Hindu namun topeng yang pada zaman Bali Klasik yang keberadaan dan wujudnya kita kenal sampai sekarang ini, digunakan untuk menyelusuri topeng khas Indonesia itu. Karena proses topeng diperkirakan mempunyai kemiripan dengan proses wayang berasal dari hiasan-hiasan atau relief candi-candi di Jawa Timur. Dimana periode ini unsur-unsur lokal Indonesia sudah menampakan diri, penggayaan ornamen

Struktur Rupa Topeng Bali Klasik (I Wayan Suardana) 
lebih dekoratif, komposisi penuh, stilasi figuratif lebih dinamis.

Kesenian dalam masyarakat Bali tak akan lepas dari agama dan adat istiadat, kesenian luluh dalam masyarakat. Seni menjadi tugas dan milik setiap orang tidak ada kata seni dan seniman dalam kehidupan budaya Bali.

Masyarakat yang terbuka dan menerima nilai-nilai baru diajadikan miliknya, walaupun sekarang telah mengalami penggeseran akibat modernisasi dari Barat melahirkan Baru. Namun kesinambungan seni tradisi seni pra-Hindu kemudian Bali Hindu Klasik tetap berlangsung sampai sekarang.

Topeng dalam kesenian yang erat kaitannya dengan upacara baik yang sifatnya sakral dan profan juga mengalami pergeseran sekarang sudah dijadikan produk komoditi akibat perkembangan arus pariwisata.

\section{DAFTAR PUSTAKA}

Agastia, IBG. 1994. Kesusastraan Hindu Indonesia. Denpasar: Yayasan Dharma Sastra

Baldinger, W.S. 1960. The Visual Art, New York: Holt Rinerhart and Winston.

Bandem, I Made, 1996, Evolusi Tari Bali. Yogyakarta: Pustaka Budaya

Kanisus. Convarrubias, M. 1977. Island Of Bali. Kualalumpur. Oxford:

University Press. Djelantik, A.A. Made. 1985. "Seni Lukis Bali Dewasa Ini di

mata Dunia". Perumusan Saresahan Seni, Taman Budaya Denpasar.

Kayam, Umar. 1981. Seni Tradisi Masyarakat. Jakarta: Sinar Harapan.

Mantra, I.B. 1993. Bali Masalah Sosial Budaya dan Modernisasi, PT. Upada Sastra, Denpasar

Murdowo. 1975. Fungsi Tapel dalam Tari Bali , Makalah Loka Karya TopengBali Denpasar

Dharmayuda, I Made Suasthawa. 1995. Kebudayaan Bali, Pra Hindu, Masa Hindu, dan Pasca Hindu. Denpasar: Kayumas Agung.

Soedarsono. 2000. "Melacak Jejak Perkembangan Seni di Indonesia". Masyarakat Seni Pertunjukan Indonesia

Tabrani, Primadi, 1993, Bahasa Rupa Wayang Beber Di Tengah Bahasa Rupa Dunia, Pameran Seni Rupa Kontemporer Dalam Rangka Pekan Wayang Indonesia VI Kebudayaan, Depdikbud.

Wardana, 1984/ 1985, Pengaruh Pariwisata Terhadap Perkembangan Seni Rupa Bali, Departemen Pendidikan Dan Kebudayaan, Proyek Pengembangan Kesenian Bali 